\title{
地盤沈下対策を目的とした大規模復水工法 \\ RECHARGE WELL METHOD FOR PREVENTION OF LAND SUBSIDENCE
}

\author{
立川喜吉*·土橋 浩** ·田 弘***.吉本豊彦**** \\ By Kiyoshi TACHIKAWA, Hiroshi DOBASHI, Hiroshi OHTA and Toyohiko YOSHIMOTO
}

\begin{abstract}
With regard to the construction of the 3 rd stage, No. 2 Haneda Tunnel for the Metropolitan Expressway Bay-Shore Route, the recharge well method was adopted to prevent the land subsidence caused by lowering of the ground water level due to pumping well. We could decrease the consolidation settlement of the ground within the allowable value by this method. This report deals with the plan, design, maintenance and effect of the recharge well method by monitoring ground water levels.
\end{abstract}

Keywords: recharge well method, pumping well, dewatering, consolidation settlement

\section{1.はじめに}

首都高速道路高速湾岸線 (3 期) 羽田第二トンネル建 設工事において大規模な山留め掘削工事を行った。掘削 地点においては被圧水頭が高く, 盤ぶくれに対する安全 率が不足するため，ディープウェルによる地下水位低下 工法を採用した.

一方, 工事地点に近接して, 羽田空港 B滑走路および 精密機械設置工場群があり, 被圧水頭低下による沖積シ ルト層の圧密沈下を許容值以内に抑える必要があった.

この対策として, 経済性・工期等を検討し，揚水した地 下水を再度地盤に注水する復水工法を採用することとし た ${ }^{1}$. 復水工法は一般的に経済性に優れているが, 注水 井戸の目づまり問題にいかに対処するかが当工法の成否 を左右するといっても過言ではない.この問題に対して, 当現場では情報化施工による井戸の機能管理を行い，本 工法の当初の目的を達成することができた.

* 首都高速道路公団湾岸線建設局京浜島工事事務所所長 ( ₹143 大田区大森北 3-43-1)

** 正会員 首都高速道路公団工務部工務企画課 ( (100 千代田区霞が関 1-4-1)

*** 正会員 (株)熊谷組土木本部土木設計部第二課主任 ( ₹162 新宿区津久戸町 2-1)

**** 正会員 (株)熊谷組土木本部土木設計部第二課 (同上)
本報文は, 当現場における復水工法の, (1)計画・設計, (2)施工，(3)管理方法，(4)効果等について述べたものであ る.

\section{2. 概 要}

\section{(1) 工 事 概 要}

本工事は, 首都圈の広域的機能の再整備, 自動車交通 の混雑緩和などの目的で, 東京湾岸道路・東京湾横断道 路・湾口部横断道路から構成される東京湾環状道路の一 環として建設されている首都高速湾岸線（3 期）および 国道 357 号のうち, 京浜島と羽田空港を結ぶ京浜南運河 横断部に位置する羽田第二トンネルの建設を行うもので ある.

施工方法としては図一1に示すように陸上部は山留め 開削工法，運河部は半川締切り開削工法²により大断面 の道路トンネルを構築するものである (写真一 1 参照). 工事主要数量を表一1に示す.

\section{(2) 地 質 概 要}

図一2 に当地域の地層断面図を示す. $N$ 值 $0 \sim 3$ の軟 弱シルト層 $\left(\mathrm{A}_{\mathrm{cl}}\right)$ が $\mathrm{TP}-5.0 \sim-19.0 \mathrm{~m}$ に層厚 6.0 $8.0 \mathrm{~m}$ で連続的に分布し, さらに部分的に別の軟弱シル 卜層 $\left(\mathrm{A}_{\mathrm{c} 2}\right)$ が $\mathrm{TP}-19.0 \mathrm{~m}$ 以深で最大約 $15.0 \mathrm{~m}$ にわ たって堆積している. 盤ぶくれ防止のために被圧水低下 


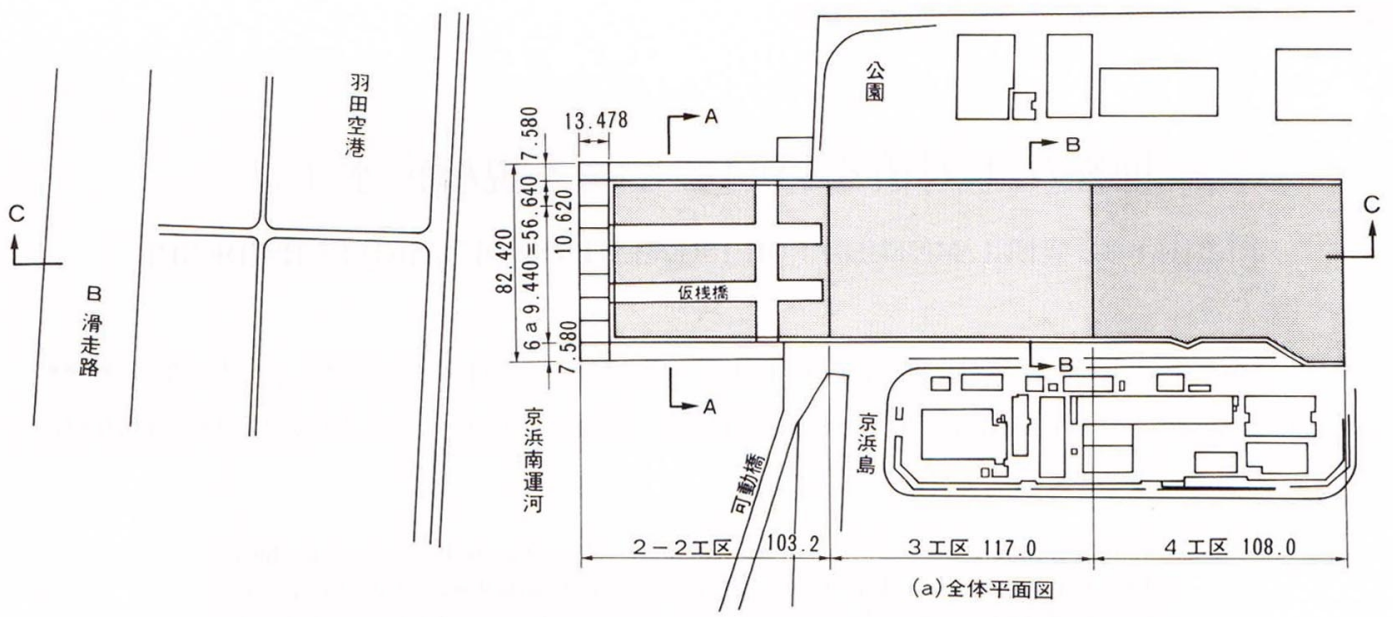

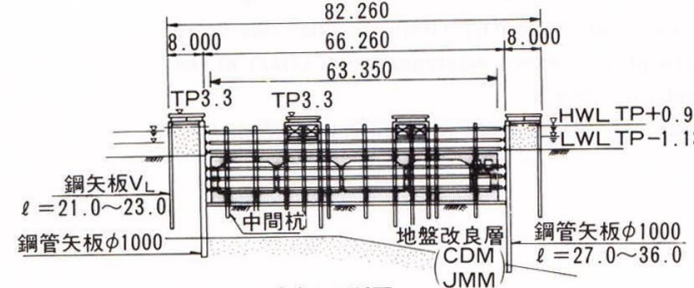

(b) A-A 断面

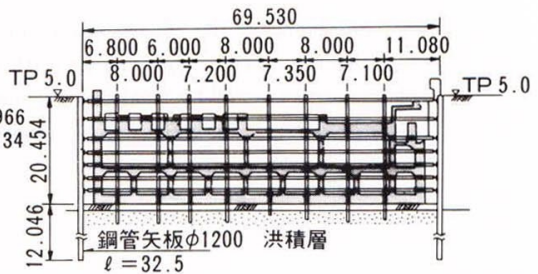

(c)B-B断面
(単位 : m)

\section{図一1工事概要}

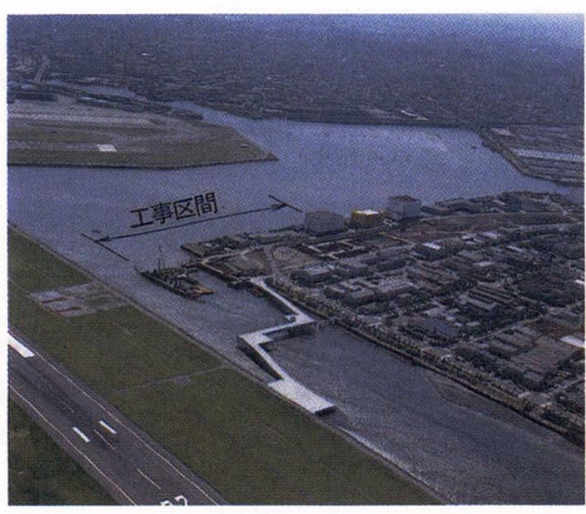

写真一1 全景写真 (1986 年6月撮影)

が必要な層は $\mathrm{D}_{\mathrm{S} 1}, \mathrm{D}_{\mathrm{s} 2}$ 層（上部带水層）および， $\mathrm{D}_{\mathrm{s} 3}$ 層 (下部帯水層) である.また, 被圧水低下による王密沈 下が問題となる層は $\mathrm{A}_{\mathrm{c} 1}$ 層と $\mathrm{A}_{\mathrm{c} 2}$ 層である.

\section{3. 現場試験}

\section{（1）現場揚水試験}

$\mathrm{D}_{\mathrm{s}}$ 層の透水性および被圧水頭を調査するため, 上部 帯水層 $\left(D_{s 1}, D_{s 2}\right)$, 下部帯水層 $\left(D_{s 3}\right)$ それぞれについ て多孔式現場揚水試験を実施した。

揚水試験は, 図一3に示す井戸配置で段階揚水試験, 一定量の揚水試験, 長期的（10日間）な一定量の揚水
表一1 主要工事数量

\begin{tabular}{|l|c|}
\hline \multicolumn{1}{|c|}{$\mathrm{I}$ 種 } & \multicolumn{1}{c|}{ 数 黾 } \\
\hline 掘 削 & $346,200 \mathrm{~m}^{\prime}$ \\
\hline 埋戻し & $66,800 \mathrm{~m}^{3}$ \\
\hline 地盤改良(CDM) & $73,350 \mathrm{~m}^{2}$ \\
\hline 地盤改良(JMM) & $14,600 \mathrm{~m}^{3}$ \\
\hline 躯体コンクリート & $93,460 \mathrm{~m}^{3}$ \\
\hline 鉄筋 (SD30) & $4,000 \mathrm{t}$ \\
\hline 鉄筋 (SD35) & $10,600 \mathrm{t}$ \\
\hline
\end{tabular}

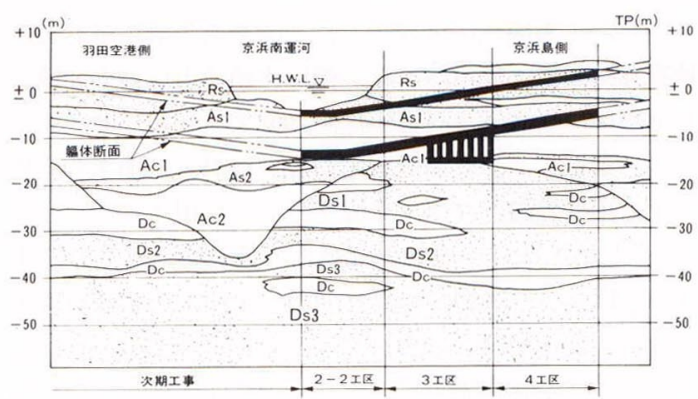

図一2 地質断面図 (C-C 断面)

試験および回復試験を実施した。さらに，潮位変動によ る地下水位変動量を測定した. データは, Jacob 法・ Thiem 法および回復法により解析し, 透水係数・貯留 係数・影響半径を求めた.

被圧帯水層の水位は, 上部帯水層, 下部帯水層とも潮 位により時間遅れなく応答し，その量は潮位変動量の約 


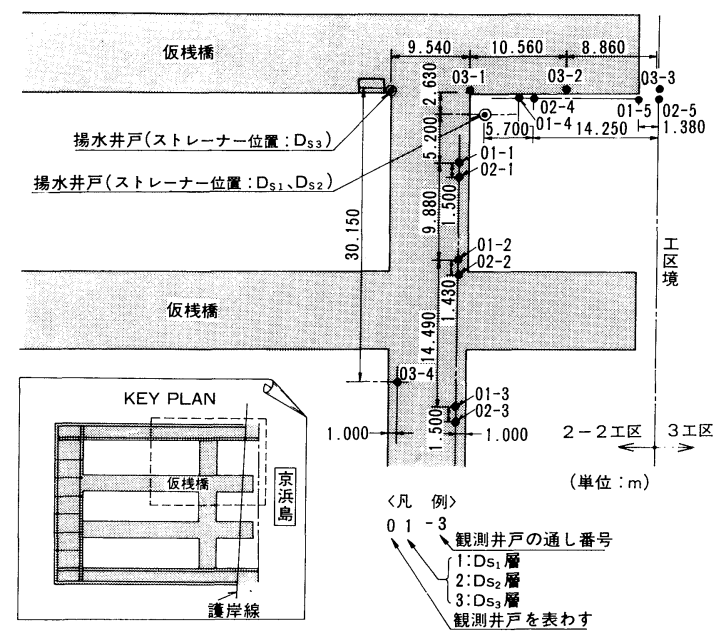

図一3 試験井戸配置

表一2 揚水試験結果（長期的な一定量の揚水試験）

\begin{tabular}{|c|c|c|c|c|c|c|}
\hline 揚水層 & 帯水層名 & $\begin{array}{l}\text { 透水量係数 } \\
(\mathrm{cm} / \mathrm{sec})\end{array}$ & $\begin{array}{l}\text { 拧留係数 } \\
\left(\times 10^{-3}\right)\end{array}$ & \begin{tabular}{|c|} 
帯水層厚 \\
$(\mathrm{m})$
\end{tabular} & $\begin{array}{l}\text { 透水係数 } \\
(\mathrm{cm} / \mathrm{sec})\end{array}$ & $\begin{array}{c}\text { 影慜半往 } \\
(\mathrm{m})\end{array}$ \\
\hline \multirow{2}{*}{$D s_{1}+D s_{2}$} & $\mathrm{Ds}_{1}$ & 2. 65 & 1.61 & \multirow{2}{*}{$\begin{array}{c}15 \\
D s_{1}+D s_{2}\end{array}$} & 1. $77 \times 10^{-3}$ & 500 \\
\hline & $\mathrm{Ds}_{2}$ & 4. 31 & 0.125 & & 2. $87 \times 10^{-3}$ & 1900 \\
\hline $\mathrm{Ds}_{3}$ & $\mathrm{DS}_{3}$ & 16.33 & 0.285 & 4 & 4. $02 \times 10^{-2}$ & 5000 \\
\hline
\end{tabular}

※ Ds 1 , Ds $s_{2}$ 層は方向によりバラッキが大きい

$25 \%$ であった。また，上部帯水層，下部帯水層の初期 水位は, 満潮時 $(\mathrm{TP}+0.966 \mathrm{~m})$ においてともに約 $\mathrm{TP}$ $-2.0 \mathrm{~m}$ であった．揚水試験結果の解析にあたっては, 潮位変動量による影響を考慮し補正した。

揚水試験の結果から算出した水理定数を表一 2 に示 す.

\section{（2）現場注水比較試験}

復水工法を実施するうえで最も問題となるのは, 注水 に伴う井戸の目づまりの発生である。この目づまり現象 は, 注入水の水質に大きく影響される。 そこで, 注水井 戸を用いて，目づまり対策工の検討用のデー夕収集を目 的として, 水道水亡現地地下水による現場注水比較試験 を実施した。

試験は，水道水を流量 $48 \mathrm{l} / \mathrm{min}$ で連続 66 時間, 引続 いて現地地下水を流量 $22 \sim 25 \mathrm{l} / \mathrm{min}$ で連続 120 時間注 水し, 井戸内水位の変化を測定した.

注水井戸の目づまりの進行速度については以下に示す 比注入量 ${ }^{3}$ で評価した。

比注入量 $\left(\mathrm{m}^{3} / \mathrm{min} / \mathrm{m}\right)=\frac{\text { 注入量 }\left(\mathrm{m}^{3} / \mathrm{min}\right)}{\text { 注水开戸内水位上昇量 }(\mathrm{m})}$

現場注水比較試験の解析フローを図一 4 に, 試験結果 を図一5に示す。

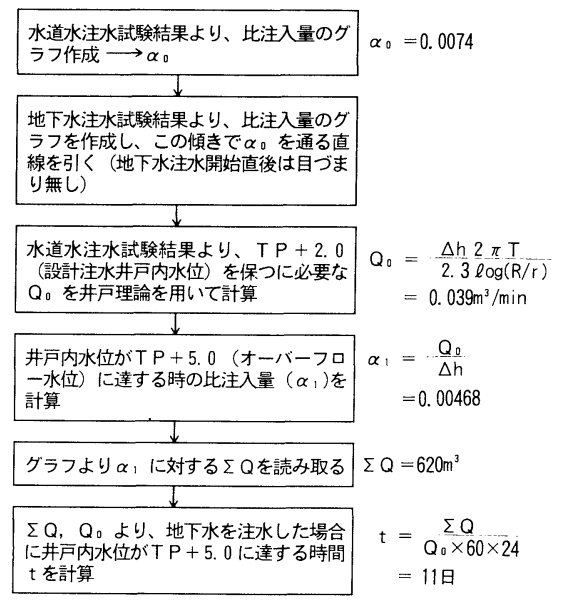

図一4現場注水比較試験解析フロー

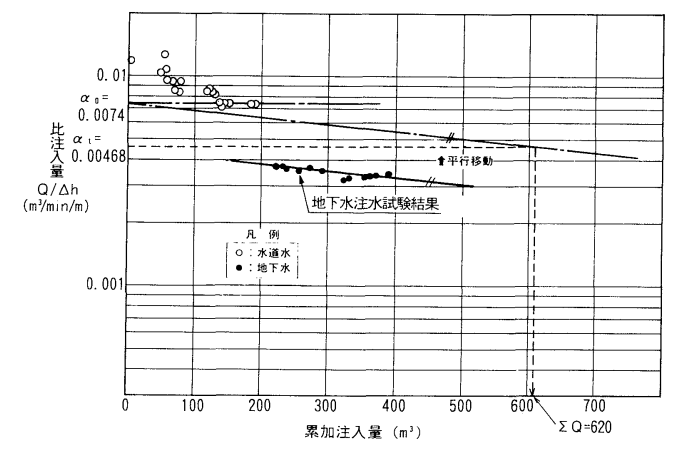

図一5 現場注水比較試験結果

水道水を注水した場合の比注入量 $(\alpha)$ は，累加注入 量 $\left(\sum Q\right)$ が増えるに従い徐々に低下し, その後一定 值となった。これは, 注水初期の非定常状態から定常状 態に移行したためと考えられ, 定常に達した時点での比 注入量を目づまりのない比注入量 $\left(\alpha_{0}\right)$ とした.

次に, 地下水の注水試験結果から, 比注入量の低下速 度 $\left(\log (Q / \Delta h) \sim \sum Q\right.$ の勾配) を求如, 図一 5 に示す ように $\alpha_{0}$ を原点として目づまりの進行度を推定するこ ととした。なお，地下水注水試駼結果のデー夕が, 累加 注入量の途中からプロットされている理由は, 当初, 水 道水と同様に $48 \mathrm{l} / \mathrm{min}$ で注水を開始したが, 途中でオ一 バーフローしていることが確認され，急きょ流量を 25 $l / \mathrm{min}$ に低下させたため, この間のデータの信頼性に問 題があると考えたためである.

一方，(1)目づまり速度の注入量依存性，(2)注水井戸の 初期水位の平面的ばらつき, (3)地層構成の複雑性などを 考えると, 今回行った試験だけでは注水による目づまり を定量的に求めることは難しいと思われるが,ここでは, 復水工法を管理していくうえで逆洗頻度の概略值を事前 に把握する必要があったことからこのような検討を行っ 
た。

検討の結果，現地地下水を注水した場合，目づまりに よって 11 日後には注水井戸内水位が注水井戸天端（TP +5.0）に達し，オーバーフローすることがわかった。 一方，復水工法の実施期間は約 14 か月間という長期間 であるため，注水として水道水を使用することは経済的 に困難であった。このため, 注水としては揚水した現地 地下水を使用せざるを得なかった。この対策としては， 注水井戸の機能回復を逆洗により適宜はかりながら注水 を行うこととした。

\section{4. 復水工法の計画・設計}

\section{(1) 井戸の配置計画}

注水井戸の本数・配置は，以下の条件を満足するよう にケーススタディーを行い，施工性も考慮して決定した (図-6 参照).

（1）工事区域と工場群との官民境界，および羽田空港 滑走路での被圧水低下による圧密沈下量の管理值を 5 $\mathrm{cm}$ とする，管理値 $5 \mathrm{~cm}$ については，建物の許容最大 沈下量（圧密沈下の場合）の標準值が $10 \mathrm{~cm}$ であるこ と（日本建築学会：建築基礎構造設計指針より)，およ び精密機械が設置してあることを考慮して決定した。

（2) 羽田空港B滑走路および精密機械設置工場群の過 度な被圧水低下を防止する.

(3) 特に, 京浜南運河を $45^{\circ}$ 方向に横切る最大厚 15 $\mathrm{m}$ の沖積シルト層 $\left(\mathrm{A}_{\mathrm{c} 2}\right)$ 上下の被圧水低下をできるだ
け防ぐ.

(4) 隣接する工事用可動橋梁の基礎は支持杭ではある が，過大な圧密沈下が発生した場合，ネガティブフリク ションによる杭応力の増加, および杭の沈下が懸念され たため，この付近の被圧水低下をできるだけ防ぐ.

また, 注水井戸の天端高は, 注水効率を上げるためで きるだけ高くして高い圧力で注水することが望ましいと も考えられたが，注水井戸が掘削地点に近いことから， 高くし過ぎると注水井戸と揚水井戸間の動水勾配が大き くなり，パイピングが懸念されたこと，さらに，周辺環 境との景観上の調和を考えて, 地盤高と同レベル (TP +5.0) とした.

\section{（2）復水工法の解析}

地下水位の変動予測は, 地層構成が複雑であるため, 帯水層の厚さの変化を考慮できるDupuit の仮定に基づ いた準三次元地下水解析により行った.

具体的な解析方法を示すと以下のようである.

(1) 上部帯水層である $\mathrm{D}_{\mathrm{s} 1}, \mathrm{D}_{\mathrm{s} 2}$ 層は，3工区（図一2 参照) で同一層となっているため, 解析上の帯水層につ いても同一帯水層とし, その厚さは $\left(\mathrm{D}_{\mathrm{s} 1}+\mathrm{D}_{\mathrm{s} 2}\right)$ とした. 下部帯水層である $\mathrm{D}_{\mathrm{s} 3}$ 層については復水工法の対象層で ないため計算上考慮していない.

(2) 透水係数は揚水試験の結果から $k=2.0 \times 10^{-3}$ $\mathrm{cm} / \mathrm{s}$ とした.

(3) 解析領域は, トンネル縦断方向に $1300 \mathrm{~m}$, 横断 方向に $1100 \mathrm{~m}$ とした。

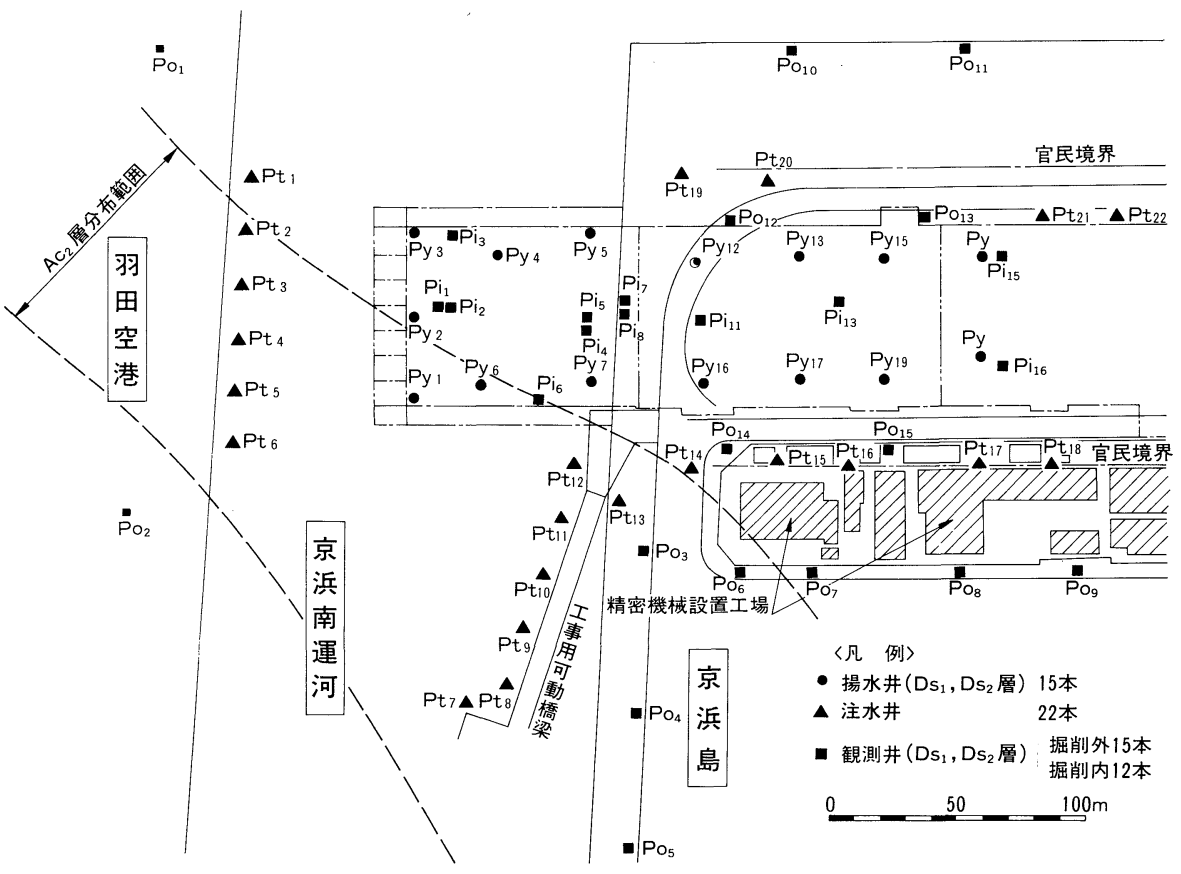

図一 6 井戸配置 
表一3 計測項目

\begin{tabular}{|c|c|c|}
\hline 計測 項 目 & 数 & 計 測 頻 度 \\
\hline 揚 水 井 水 位 & 19 & 1 回 $/ 5$ 分 $^{*}$ \\
\hline 注 水 井 水 位 & 22 & $\prime \prime$ \\
\hline 観 測 井 水 位 & $31\left(\begin{array}{l}\text { 掘削内 : 16 } \\
\text { 掘削外：15 }\end{array}\right)$ & " \\
\hline 揚 水 井 流 量 & 19 & 1 回 / 日 \\
\hline 注 水井流 量 & 22 & " \\
\hline 地盤沈下 (水準測量) & 57 & 2 回 $/$ 月 \\
\hline
\end{tabular}

(4) 解析にあたっては揚水井戸, 注水井戸ともに水位 固定とした。注水井戸については地盤高 $\mathrm{TP}+5.0$ に対 して多少安全側をみて $\mathrm{TP}+2.0$ で水位固定, 揚水井戸 の水位については盤ぶくれに対する安全率 $\left(F_{a}=1.2\right)$ を満足するように繰り返し計算を行った。盤ぶくれに対 する安全率を満足するような掘削域の必要水位低下量 は, 地層構成が複雑なため平面的にいくつかのブロック に分けて計算した。

周辺地盤の沈下予測は, 地下水位低下量をもとにテル ツァーギーの一次元圧密理論により行った.計算方法は, $e \sim \log P$ 曲線による方法とした. 圧密係数は土質試験 の結果から $\mathrm{A}_{\mathrm{c} 1}, \mathrm{~A}_{\mathrm{c} 2}$ 層でそれぞれ $579 \mathrm{~cm}^{2} /$ day, 810 $\mathrm{cm}^{2} /$ dayとした.

\section{(3) 計測計画}

主に盤ぶくれの管理と復水工法の管理を目的に, 表一 3 に示す計測を行った. 表中の*印については, パソコ ンによる自動計測とし，計測は 5 分ごとに行い，盤ぶく れに対する安全率および井戸内水位をパソコンのディス プレイに常時表示可能とした ${ }^{4)}$. 盤ぶくれに対する安全 率, および井戸内水位が管理值を越えた場合には, 計測 室および事務所において警報が作動するようにした.

計測システム構成を図一7に, 計器設置位置を図一8 に示す.

\section{（4）目づまり対策}

注水井戸の目づまりは, 表一4 に示すような種々の原 因が考えられる5!.

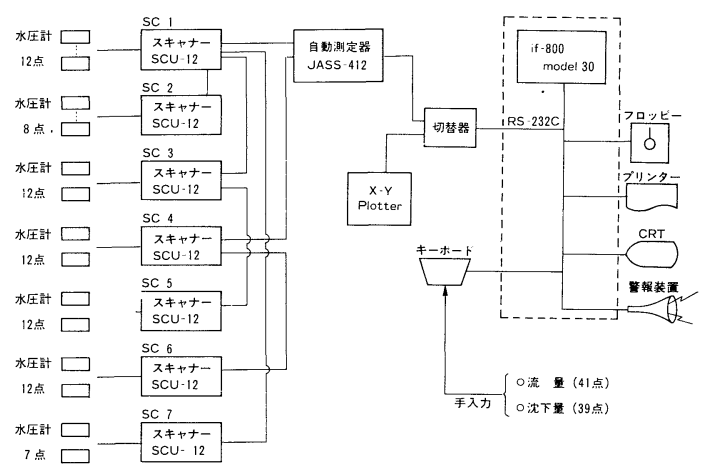

図一7 システム構成図

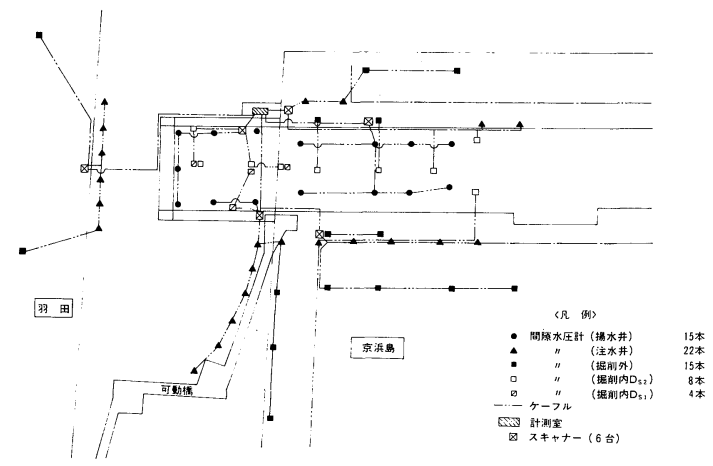

図一8 計器設置平面図（上部帯水層）

当現場の地下水は, 特に, 溶解鉄 $(\mathrm{Fe})$ ・マンガン $(\mathrm{Mn})$ の濃度が高く $(\mathrm{Fe}=26 \mathrm{mg} / l, \mathrm{Mn}=3 \mathrm{mg} / l)$, このよう な地下水がいったん空気に触れると, $\mathrm{Fe}_{2} \mathrm{O}_{3}, \mathrm{Mn}_{2} \mathrm{O}_{3}$ の 形に変化し, これらが注水井戸の近傍地盤に蓄積して目 づまりが発生する (写真一2 参照). 前述の比較注水試 験の結果からは, 約 2 週間で注水井戸としての機能が果 たせなくなることがわかっており, 事前の目づまり対策 を以下のとおりとした.

(1) 注水中の空気混入を少なくするために, 受水槽の 位置を注水井戸天端から $2 \mathrm{~m}$ 程度高くするとともに, 注水井戸内の注水管を井戸内水位以下まで延ばし, 注水 が注水井戸内を自由落下しないようにした。

(2) 井戸のスクリーン部の酸化による影響を防止する ため,スクリーン部の網を樹脂系にした.

表-4 目づまりの原因

\begin{tabular}{|c|c|c|}
\hline 目づまりの原因 & 概 & 対 \\
\hline $\begin{array}{l}\text { 井戸掘削中 } \\
\text { の泥によ } \\
\text { る目づまり }\end{array}$ & $\begin{array}{l}\text { リチャージエ法の成否は、注水 } \\
\text { 井の譏能に左右されるため、施エ } \\
\text { には最善の注意が必要である。 }\end{array}$ & $\begin{array}{l}\text { (1)井戸施工時の十分な洗 } \\
\text { 浄 } \\
\text { (2)揚水による洗浄 } \\
\text { 3確実なフィルター材の } \\
\text { 充てん }\end{array}$ \\
\hline $\begin{array}{l}\text { 注入水中の } \\
\text { 惩濁物質 }\end{array}$ & 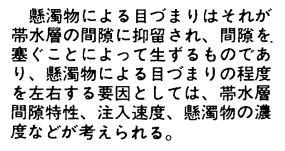 & $\begin{array}{l}\text { 1注入水(揚水)は、沈殿 } \\
\text { 槽、フイルター通し } \\
\text { た後、注水する。 }\end{array}$ \\
\hline $\begin{array}{l}\text { 注入水や帯 } \\
\text { 水層中の微 } \\
\text { 生物の增殖 }\end{array}$ & 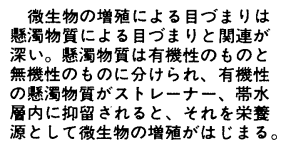 & $\begin{array}{l}\text { フフィルターによる洗浄 } \\
\text { 2 注水温度を高くしない } \\
\text { (水槽、配管) }\end{array}$ \\
\hline 気 泡 & 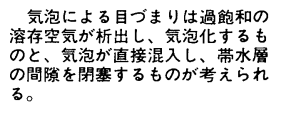 & $\begin{array}{l}\text { I下図に示す様な万法に } \\
\text { より、できるだけ気泡 } \\
\text { を入れない樓造とする。 }\end{array}$ \\
\hline $\begin{array}{l}\text { 溶解鉄、 } \\
\text { マンガンの } \\
\text { 酸化及び } \\
\text { ストレーナ } \\
\text { ンチーシ } \\
\text { ングの腐食 }\end{array}$ & 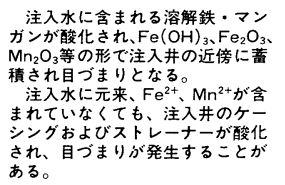 & $\begin{array}{c}\text { (1ステンレスなど腐食し } \\
\text { にくい材質にする。 }\end{array}$ \\
\hline
\end{tabular}




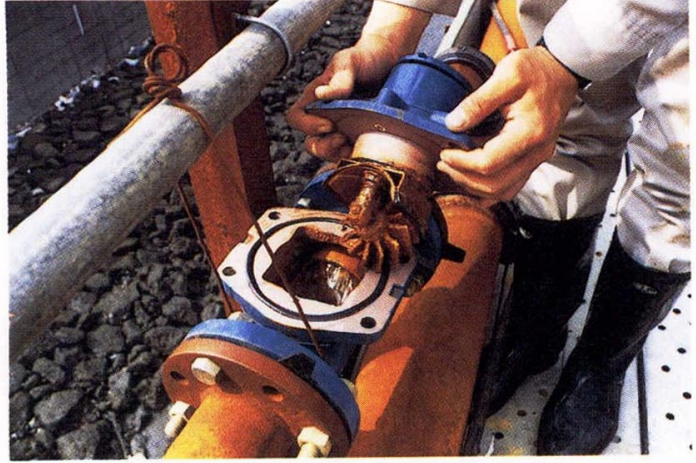

(a) 洗浄前

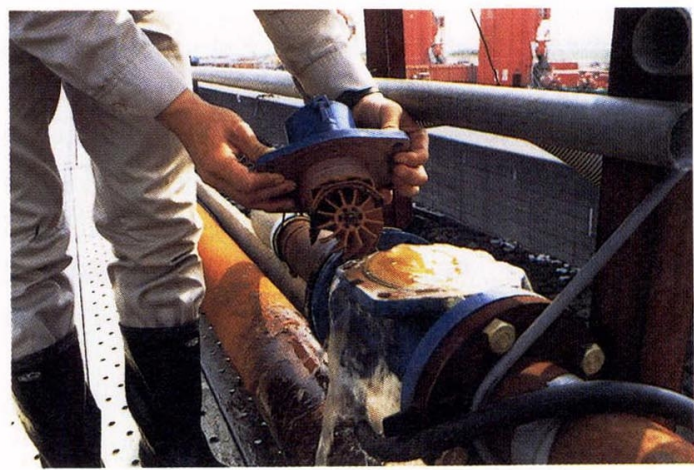

(b) 洗净後

写真一2 流量計翼への酸化鉄の付着

（3）羽田空港側については，注水効率をできるだけ高 めるため, 注水が空気に触れないように揚水井戸〜注水 井戸間の配管を直結した。

(4) 注水井戸内には，揚水用ポンプを常設し，目づま りによる注水効率が低下した場合は, 揚水と注水を繰り 返す方法 (逆洗 ${ }^{61}$ ) により井戸機能の回復をはかった. なお，逆洗の方法としては文献 6) を参考にして，揚水 と注水を 30 分程度繰り返し, 揚水が澄んできたことを 確認してストップすることとした.

逆洗による注水井戸の管理については6. で詳細に述 ベる.

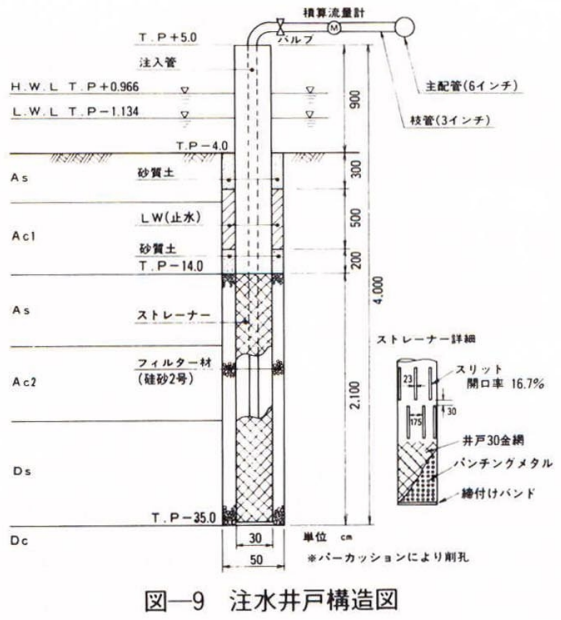

（5）停電対策

停電により, 揚水ポンプが停止した場合には, 被圧地 下水位上昇に伴う盤ぶくれの危険性があるため, 以下の 対策を行った.

（1) 各掘削段階で，各揚水井戸の側面に穴をあけ，揚 水ポンプが停止した場合にはこれらの穴から地下水が流 れ出る構造とした (リリーフウェルの機能).

(2) 二次電源としてジェネレーターを設置し， 3〜5 分程度で揚水ポンプが再稼働できる設備とした。

工事中幾度かポンプの故障や停電が生じたが, 穴から の湧水により地下水位の急激な上昇を抑えることができ た.

\section{5. 井戸の施工}

井戸の構造を図一9に, 注水井戸の設置状況を写真一 3 に示す. 揚水ポンプは, 3 インチ, $7.5 \mathrm{~kW}, 45 \mathrm{~m}$ 高揚 程のものを, 注水井戸内逆洗用ポンプは, 2 インチ, 5.5 $\mathrm{kW}, 28 \mathrm{~m}$ 高揚程のものを使用した.

\section{6. 復水工法の管理}

注水井戸の目づまり対策は不確実な面が多いため事前

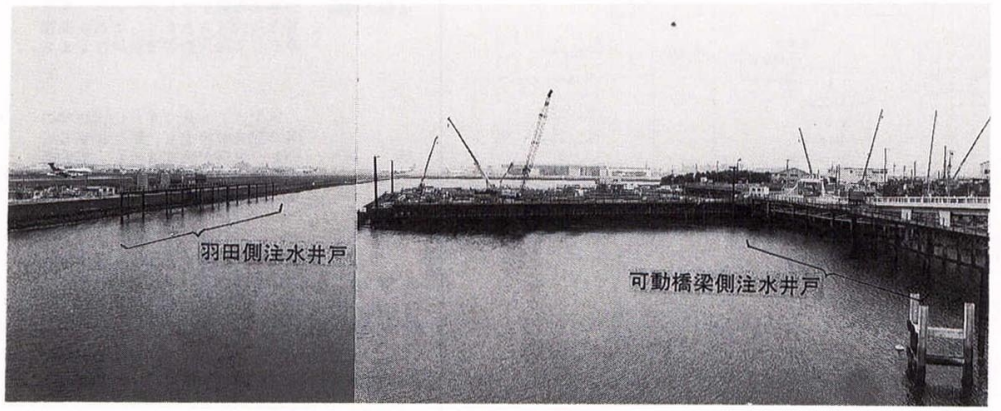

写真一3 注水井戸設置状況 
の予測のみで対処することは困難である.そこで, 復水 工法開始後, 計測結果をもとに地盤の透水係数, 圧密定 数などを修正し (以下現状解析という), 次の施工段階 における地下水位の変動, 沈下量の予測（以下予測解析 という）を行い，管理值を越えると予測された場合には 計画を変更していく, いわゆる, 情報化施工を採用した.

注水井戸の目づまりの回復は, 逆洗による方法が一般 的であるが，逆洗を用いた復水工法の管理方法は試行錯 誤に頼っているのが現状である.この問題に対して, 当 現場においては, 以下に示す方法で対処した（図一10 参照).

(1) 復水工法開始後, 現状の計測結果をもとに現状解 析を行い, 透水係数を推定する. また, 比注入量グラフ により実績注水量から可能注水量および逆洗頻度を推定 する.

(2) 掘削内の必要水位低下量, および設計注水量をも とに周辺水位を予測する (準三次元地下水解析). それ をもとにテルツァーギーの一次元圧密理論により周辺地 盤沈下量を計算する.

(3) 計算された沈下量と管理値 $(5 \mathrm{~cm})$ を比較し, 計算值が管理值を越えると予測された場合には, 注水井 戸の増設または水質浄化装置の設置の検討を行う．計算

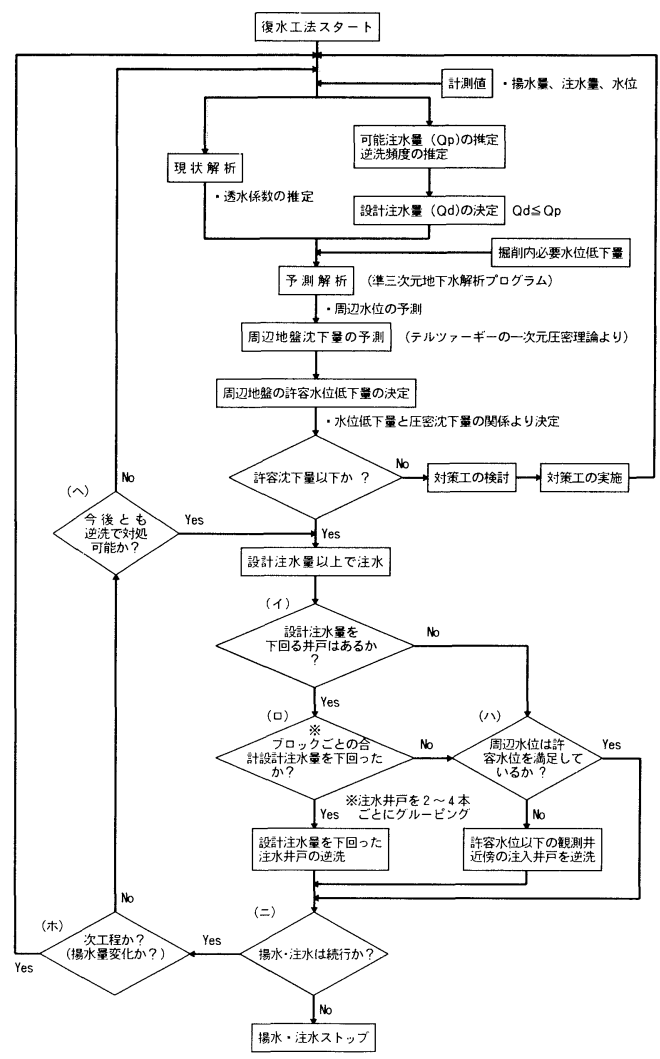

図一10 復水工法管理フロー
值が管理值以下の場合には，そのまま設計注水量以上で 注水を続ける.

(4) 日常管理としては図一10中の（イ〜（ハ）の判 定条件に従い逆洗を実施する. 具体的にはブロックごと の合計注水量がブロックごとの合計設計注水量を下回っ た場合には，設計注水量を下回った注水井戸についての み逆洗を実施する。 また，（八）で示したように実測水 位が許容水位より低下した場合には許容水位を下回った 観測井戸の近傍の注水井戸を逆洗する.（口）の判定を 取り入れた理由は, ブロックごとの合計設計注水量が満 足されていれば, 問題となるような周辺地盤の水位低下 が生じないことが事前の解析により明らかになっていた からである.

(二)〜(へ) の判定に従い, 次工程のため揚水量を増 加する必要がある場合, または, 目づまりが激しく, 逆 洗で今後の対処が不可能と思われた場合には, 再度(1)か らの検討を行う.

\section{7. 復水工法の効果}

\section{（1）地下水位低下量}

復水工法を採用した場合と採用しない場合の水位低下 量 (解析值) を図一11に示す. 図一11の（b）は, 準 三次元地下水解析により, 最終床付時の揚水量, 注水量 および周辺水位の実測值に計算值ができるだけ一致する ように透水係数をパラメーターとして繰り返し計算した 結果である.この解析から推定された上部帯水層の透水

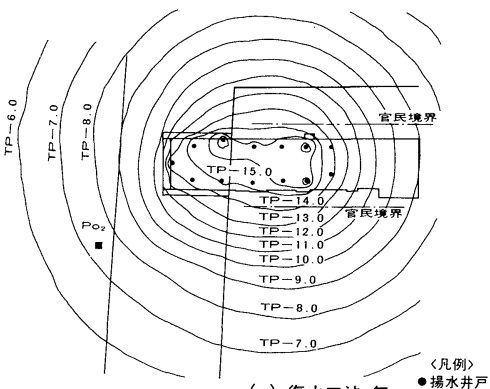

（a）復水工法 無

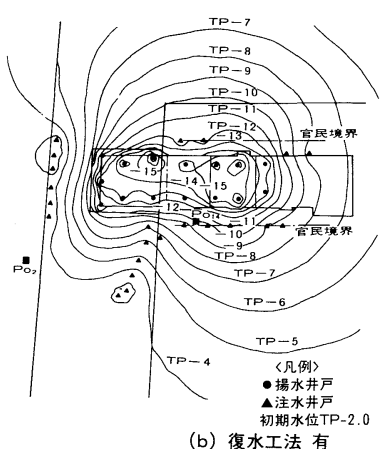

図-11 地下水位低下量（最終床付時） 


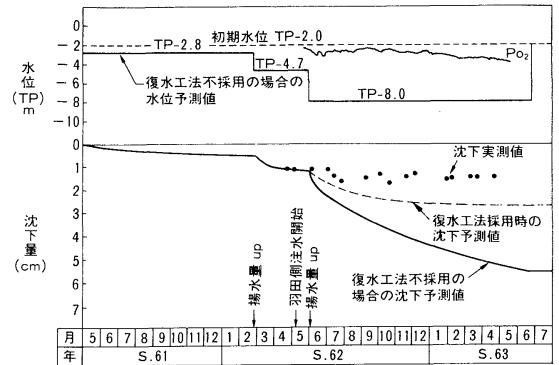

(a) 羽田空港 $\left(\mathrm{PO}_{2}\right.$ 地点)

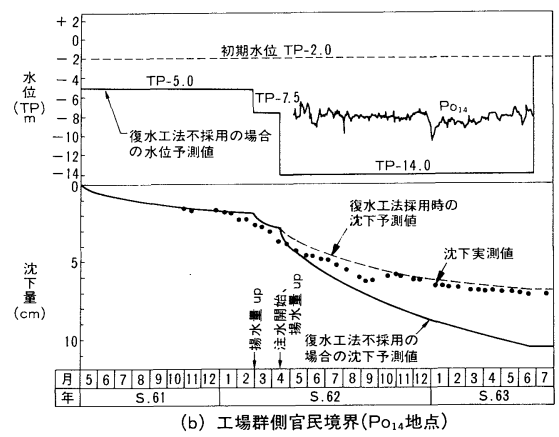

図一12 地盤沈下量（予測值は最終床付け時（62 年10月）に おける解析結果)

係数は， $k=1.24 \times 10^{-3} \mathrm{~cm} / \mathrm{s}$ であった（揚水試験より 求めた透水係数は, $\mathrm{D}_{\mathrm{s} 1}$ 層で $1.77 \times 10^{-3} \mathrm{~cm} / \mathrm{s}, \mathrm{D}_{\mathrm{s} 2}$ 層で $\left.2.87 \times 10^{-3} \mathrm{~cm} / \mathrm{s}\right)$.

一方，（a ）は，（b）で推定した透水係数をもとに復 水工法を採用しなかった場合の水位を計算した結果であ る.（b）の結果は実測水位とほぼ一致しており，（a） と（b）の差が復水工法による効果を表わしている.

\section{（2）地盤沈下量}

羽田側および工場群側官民境界での沈下量の実測值, および解析值を図一12に示す.

工場群側官民境界の最終沈下量は, 約 $7.0 \mathrm{~cm}$ であっ た，官民境界と山留め壁の距離は $20 \mathrm{~m}$ と近いため, 実 測沈下量には山留壁の変形による影響が含まれる.山留 め壁の変形による地表面沈下量をPeck の方法?（地盤 の種類, 掘削深さ, 山留め壁からの距離により沈下量を 推定), 丸岡らの方法 ${ }^{7)}$ (山留め壁の最大変形量, 掘削 深さ, 山留め壁からの距離により沈下量を推定), およ び国鉄指針による方法 ${ }^{8)}$ (山留め壁の変形面積と背面沈 下面積が等しいとして算定）により推定すると約 $2 \mathrm{~cm}$ であることから，圧密沈下量としては $5 \mathrm{~cm}$ 程度と思わ れる. 実測沈下量 $(7 \mathrm{~cm})$ は管理值 $(5 \mathrm{~cm})$ を多少越 える結果となったが，施工途中（最終掘削時）で行った 工事完了時の沈下予測值 (約 $7 \mathrm{~cm}$ ) が許容最大沈下量 $(10 \mathrm{~cm})$ 以下であったこと，また，周辺の工場に影響 が出ていなかったことから特別な対策は施さなかった.

羽田側については最終沈下量は約 $1.5 \mathrm{~cm}$ であった.

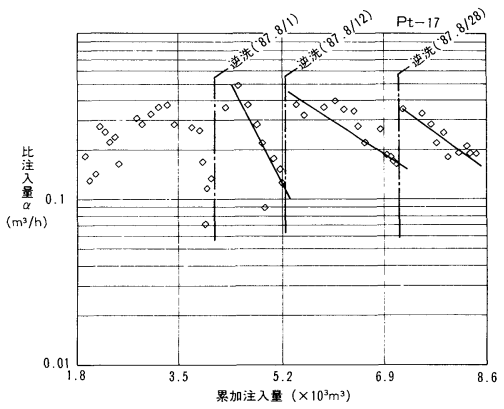

(a) 短期

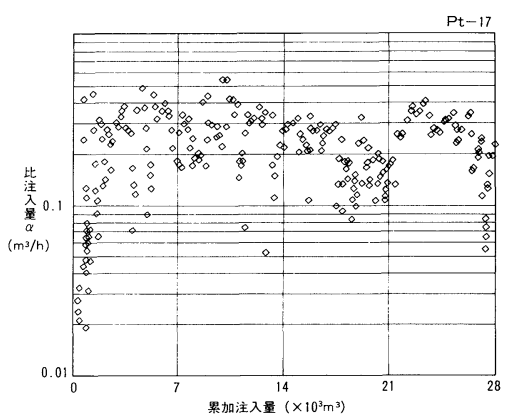

(b) 長期 (S. 62.6/1 S. 63.4/10)

図一13 注水井戸の効率低下

工場群側に比べて沈下量が小さい理由は，揚水地点から 距離が離れているため水位低下量が少なかったこと, 羽 田側配管ルートを直結にした効果により当ルートの注水 井戸の効率の低下を他の注水井戸のそれに比べて小さく できたことによると考えられる。

\section{（3）目づまりの速度と逆洗頻度}

工場群側注水井戸の注水量と水位を比注入量グラフに より整理した結果を図一13に示す.

1〜2 週間間隔で逆洗を繰り返すことにより井戸機能 を持続することができ，結果として注水井戸の増設など の対策工を実施せずに済んだ.

\section{（4）総揚水量と総注水量の関係}

2-2 工区の総揚水量と総注水量の経時変化を図一14 に 示す. 総揚水量に対する総注水量の比率は 50 90\% で あった。

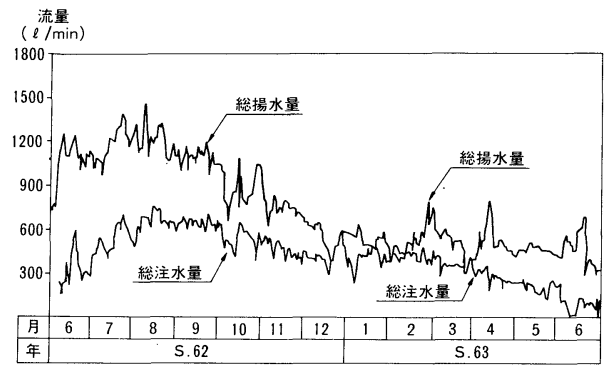

図一14 総揚水量と総注水量の経時変化（2-2 工区） 


\section{8. 今後の課題}

今後の課題としては, 以下に示すことが考えられる.

(1) Deep Wellにより揚水した地下水の酸化防止方 法.

(2) 酸化した地下水の経済的な浄化の方法.

(3) 目づまりを起こしにくい, または回復が容易な注 水井戸の構造.

(4) 目づまりの程度の確認方法と逆洗実施時期の決定 方法の改善, および効果的な逆洗の方法.

(5) 目づまり現象の事前予測の方法.

\section{9. おわりに}

復水工法は，一般的に経済性に優れているが，注水井 戸の目づまりの予測方法, 対策等は今後とも研究してい かなければならない課題である．当現場においては，情 報化施工による管理手法により, 逆洗を繰り返し実施し, 沈下量を許容値内に抑えることができた.

\section{参 考 文 献}

1）土橋 浩·上田敏雄・大田 弘・吉本豊彦·生駒尚己： 地盤沈下対策としての復水工法の実施例, 第 43 回年次学 術講演会講演概要集, pp. $216 \sim 217$, 昭和 63 年 10 月.

2）林 紀夫・関口隆史・岸 研司：半川締切りの施工例一 首都高速，京浜南運河一，基礎工，pp. 44 52，1987 年 4 月.

3）地下水ハンドブック，建設産業調查会, p. 1297, 昭和 54 年 9 月 8 日.

4）大田 弘・吉本豊彦・生駒尚己ほか：山留め·地下水情 報化施工管理システムの開発, 土木学会第 44 回年次学術 講演会, 1989 年 10 月.

5）地下水ハンドブック，建設産業調査会，pp. 1293～1302, 昭和 54 年 9 月 8 日.

6) 長井 茂・村下敏夫：人工地下水における注水井戸の目 づまりと井戸能力の回復 (妻沼実駼地の例), 工業用水, 第 170 号, pp. 48 54, 昭和 47 年11 月.

7) 山留为設計施工指針, 日本建築学会, pp. 57 58, 1988 年.

8）掘削山留工設計指針 (案), 社団法人日本鉄道施設協会, pp. 107 ，昭和 54 年.

(1989.12.5 • 受付)

本文が類似工事の参考になれば幸いである. 